\title{
Legal and Corruption Issues in Sports Gambling
}

\author{
Ryan M. Rodenberg \\ Florida State University \\ Anastasios Kaburakis \\ Saint Louis University
}

\begin{abstract}
Twenty years after its enactment, this article critically analyzes the Professional and Amateur Sports Protection Act (PASPA) in light of recent litigation and policy shifts pertaining to one of the most prominent sports gambling statutes at the federal level. Our foci are two-fold. First, we detail PASPA origins and compare it with related federal and state laws. Our legal discussion then turns to an exploration of two timely lawsuits that challenged PASPA —one in Delaware (2009) and one in New Jersey (2011). Second, we explore the economic foundations of sports gambling generally, with a specific discussion of the impact of technological advances. Similarly, we explain how integrity issues that were the impetus for PASPA remain germane today in light of rising levels of corruption in the sport gambling sector. We conclude by highlighting policy considerations at the government and league level that will likely determine PASPA's viability and legality moving forward.
\end{abstract}

On April 15, 2011, the federal government shut down the three largest online poker sites servicing the American market: Full Tilt Poker, PokerStars, and Absolute Poker/Ultimate Bet. ${ }^{1}$ The shutdown was subsequently labeled Black Friday in the mainstream press. ${ }^{2}$ In addition to seizing the assets of each of the aforementioned

\footnotetext{
${ }^{1}$ Press Release, U.S. Att'y Off., S.D.N.Y., Manhattan U.S. Attorney Charges Principals of Three Largest Internet Poker Companies with Bank Fraud, Illegal Gambling Offenses, and Laundering Billions in Illegal Gambling Proceeds (April 15, 2011), available at http://www.justice.gov/usao/ nys/pressreleases/April11/scheinbergetalindictmentpr.pdf.

${ }^{2}$ Matt Richtel, U.S. Cracks Down on Online Gambling, N.Y. Times (April 15, 2011), available at http://www.nytimes.com/2011/04/16/technology/16poker.html?_r=1; Darren Rovell, Insider Breakdown of Poker's Black Friday, CNBC (April 18. 2011), http://www.cnbc.com/id/42649117; Nate Silver, After 'Black Friday,' American Poker Faces Cloudy Future, N.Y. Times (April 20, 2011), available at http://fivethirtyeight.blogs.nytimes.com/2011/04/20/after-black-fridayamerican-poker-faces-cloudy-future/.
}

Rodenberg is with the Dept. of Sport Management, Florida State University, Tallahassee, FL. Kaburakis is with the John Cook School of Business, Dept. of Management, Saint Louis University, St. Louis, MO. 
online poker operators, each affiliated website included stern notices from the Department of Justice (DOJ) and Federal Bureau of Investigation (FBI) informing visitors that certain gambling is illegal under federal law. Less than two months later, the online sports gambling industry was also subject to a federal-level enforcement action dubbed Blue Monday.

The Blue Monday indictments, released May 23, 2011, targeted a number of individuals and entities involved, at least tangentially, to online sports gambling. ${ }^{3}$ Ten sports gambling websites were shut down as a result. ${ }^{4}$ The indictments resulted from a two-year multi-agency state and federal investigation that involved the creation and operation of an undercover payment processing firm that allowed law enforcement agents to interact directly with gambling organizations. An affidavit filed in conjunction with the indictment detailed intricate aspects of online sports betting and shed light on the lifeblood of internet-based sports gambling: payment processing, a prerequisite to any virtual portal accepting sports wagers from a remote location. Payment processing is a two-way street, with such processors collecting money from gamblers for their accounts and paying out winnings to gamblers upon request.

Citing cases dating back to the years following the Civil War, Major League Baseball's anti-gambling stance has been described as a long-term crusade. ${ }^{5} \mathrm{~A}$ noted scholar described gambling as "the deadliest sin in sports." 6 The United States government's move to criminalize operators servicing domestic sports gamblers wagering offshore highlights more than a century of tension between sports and gambling. Measuring the impact of gambling-related corruption on the integrity of sports has also been addressed. ${ }^{7}$ The unique role of gambling in the collegiate

\footnotetext{
${ }^{3}$ Press Release, U.S. Att'y Off., D.Md., Operators of Internet Gambling Sites and Their Businesses Indicted for Running An Illegal Gambling Business and Money Laundering (May 23, 2011), available at http://www.justice.gov/usao/md/Public-Affairs/press_releases/press08/ OperatorsofInternetGamblingSitesandTheirBusinessesIndicted.html.

${ }^{4}$ The following internet domain names were seized pursuant to court order: Bookmaker.com, 2Betsdi.com, Funtimebingo.com, Goldenarchcasino.com, Truepoker.com, Betmaker.com, Betgrandesports.com, Doylesroom.com, Betehorse.com, and Beted.com.
}

${ }^{5}$ Thomas J. Ostertag, From Shoeless Joe to Charley Hustle: Major League Baseball's Continuing Crusade against Sports Gambling, 2 Seton Hall J. Sport L. 21 (1992).

${ }^{6}$ Paul C. Weiler, Leveling the Playing Field 31 (2000).

${ }^{7}$ See Richard H. McLaren, Corruption: Its Impact on Fair Play, 19 Marquette Sports L. Rev. 15 (2008) (providing examples from professional sports and international competitions, emphasizing the need for sport governing bodies to promote educational efforts on the deleterious effect of gambling-related corruption in sport compromising uncertainty of results); Adam Hosmer-Henner, Preventing Game Fixing: Sports Books as Information Markets, 14 Gaming L. Rev. Econ. 31 (2010) (arguing that instead of harsher anti-gambling policy, sports leagues and legislators should treat sports books as more regulated information markets and "formalize mutually beneficial relationships"). For a contrasting view, see Jeffrey Standen, The Beauty of Bets: Wagers as Compensation for Professional Athletes, 42 Willamette L. Rev. 639 (2006) (advocating freedom to place bets even by athletes would result in fewer incentives to throw games and would bolster sports' appreciation by the consuming public). 
sports context has also been analyzed. ${ }^{8}$ From a lawmaking standpoint, a leading expert posited that "American policymakers have literally ceded sports betting to organized crime while the market continues to grow." 9 A near-apocalyptic view of gambling's interaction with sports was summed up in a prominent 1986 Sports Illustrated article:

Nothing has done more to despoil the games Americans play and watch than widespread gambling on them. As fans cheer their bets rather than their favorite teams, dark clouds of cynicism and suspicion hang over games, and possibility of fixes is always in the air. ${ }^{10}$

The purpose of this article was to analyze the legal and corruption-focused underpinnings of federal statutes that impact sports betting. One foci was on the Professional and Amateur Sports Protection Act (PASPA) in a post-internet world, where the scope and diversity of sports wagering differ markedly from the time PASPA was debated and enacted in the early 1990s. ${ }^{11}$ The enforcement actions on Black Friday and Blue Monday, coupled with recent sports gambling-related litigation involving Delaware and New Jersey, have thrust PASPA and the other statutes back into the spotlight. The remainder of this article is organized as follows: Section I highlights relevant federal and state law, Section II focuses narrowly on PASPA, Section III examines how corruption concerns have shaped federal legislation pertaining to sports gambling, Section IV explains the resulting policy issues, and Section V concludes with an outlook to the future.

\section{Primer on Statutory Provisions}

\section{Federal}

Wire Act of 1961. In the 1950s, there was widespread coverage of organized crime networks and their influence in interstate commerce. ${ }^{12}$ Democratic Senator Estes Kefauver from Tennessee introduced a resolution that led to the formation of the Special Committee to Investigate Organized Crime in Interstate Commerce, also referred to historically as the Kefauver Committee. This committee held hearings

\footnotetext{
8 John Grady \& Annie Clement, Gambling and Collegiate Sport, 15 J. Legal Aspects of Sport 96 (2005) (summarizing efforts to render gambling on college sports illegal in Nevada and providing recommendations including a system of criminal sanctions similar to insider trading).

${ }^{9}$ Sue Schneider, Better Odds for Sports Betting, 14 Gaming L. Rev. Econ. 515 (2010).

${ }^{10}$ John Underwood et al., The Biggest Game in Town, Sports Illustrated (March 10, 1986) available at http://sportsillustrated.cnn.com/vault/article/magazine/MAG1064574/5/index.htm.

${ }^{11}$ For the avoidance of doubt, this article will not address the important topic of societal costs stemming from gambling. For a detailed discussion of this topic, see Doug. M. Walker \& A. H. Barnett, The Social Costs of Gambling: An Economics Perspective, 15 J. Gambling Stud. 181 (1999).

${ }^{12}$ See generally William N. Thompson, Gambling in America: An Encyclopedia of History, Issues, and Society (2001); Steve Durham \& Kathryn Hashimoto, The History of Gambling in America (2010); see also Special Committee to Investigate Organized Crime in Interstate Commerce, Guide to Fed. Rec. Nat'l Archives U.S. (1950), available at http://www.archives.gov/legislative/guide/ senate/chapter-18-1946-1968.html\#E-2.
} 
that were occasionally publicly broadcasted. The public was made aware of a very broad network of illicit betting schemes, controlling information pertinent to betting activity, as well as the related corruption of police and public officials. ${ }^{13}$ One of the recommendations by the Kefauver Committee to the federal government was to legislate against any betting taking place over the radio, television, telegraph, and telephone. The seeds planted by the Kefauver Committee became federal law during the Kennedy administration, morphing into the Wire Act of 1961 (Wire Act). ${ }^{14}$ The Wire Act reads

Whoever being engaged in the business of betting or wagering knowingly uses a wire communication facility for the transmission in interstate or foreign commerce of bets or wagers or information assisting in the placing of bets or wagers on any sporting event or contest, or for the transmission of a wire communication which entitles the recipient to receive money or credit as a result of bets or wagers, or for information assisting in the placing of bets or wagers, shall be fined under this title or imprisoned not more than two years, or both. ${ }^{15}$

In subsection (b), however, the Wire Act provides a safe harbor provision:

Nothing in this section shall be construed to prevent the transmission in interstate or foreign commerce of information for use in news reporting of sporting events or contests, or for the transmission of information assisting in the placing of bets or wagers on a sporting event or contest from a State or foreign country where betting on that sporting event or contest is legal into a State or foreign country in which such betting is legal. ${ }^{16}$

Although its safe harbor provision protected considerable activity that had been traditionally inherent in sport betting transactions, the Wire Act has been utilized by federal authorities to prosecute illicit gambling. One of the most highly publicized Wire Act cases was United States v. Cohen. ${ }^{17}$ Cohen, an American, was convicted on Wire Act violations emanating from his World Sports Exchange (WSEX) gambling portal that was established in and operating online from Antigua. After being indicted, Cohen voluntarily returned to the U.S. and prepared a full defense. To gather evidence, undercover federal agents maintained gambling accounts on Cohen's website, transferred money to such accounts, and placed online and telephone bets. ${ }^{18}$ Eventually, Cohen was found guilty of administering an online sports book that accepted wagers from Americans over the phone and the internet, thus

\footnotetext{
${ }^{13}$ Durham \& Hashimoto, supra note 12, at 42-43; Gambling Proposals Lose in Four States, Christian Century, November 22, 1950, at 1380; Thomas Harris, Winner Take All: Expansion of the Gaming Industry, Western Wire, Fall 1994, at 18.

1418 U.S.C. $\$ 1084$ (2012).

${ }^{15} \mathrm{Id} . \S 1084(\mathrm{a})$.

${ }^{16} I d . \S 1084(\mathrm{~b})$.

${ }^{17}$ United States v. Cohen, 260 F.3d 68 (2d Cir. 2001).

18 See, e.g., United States v. Bodog Entm't Group (Dist. MD, Feb 27, 2012) (the most recent federal sting operation targeting Bodog.com) available at http://scholar.google.com/scholar_cas e? case $=11044190561272741296 \& \mathrm{hl}=\mathrm{en} \&$ as_sdt $=2,26$.
} 
in violation of the Wire Act. ${ }^{19}$ The result of the Cohen case provided evidence that sports books accepting wagers from U.S. residents would not avoid prosecution by merely locating themselves offshore. The Cohen case clearly demonstrated that the Wire Act applied to online sports books, even though the statute preceded the advent of the internet by almost four decades.

Despite the findings in Cohen, a retrospective analysis of relevant case law and policy statements indicates that the Wire Act cannot be used to prosecute individual bettors. ${ }^{20}$ In re MasterCard International was a case involving online casino gamblers who tried to get their credit card debts ruled unenforceable because their online casino gambling had been illegal. ${ }^{21}$ The U.S. Court of Appeals for the Fifth Circuit declared in 2002 that gambling losses were indeed enforceable because "the Wire Act does not prohibit non-sports internet gambling," ${ }^{22}$ a decision with which the DOJ disagreed. ${ }^{23}$ DOJ officials took the same position (supporting broader scope coverage of the Wire Act) when advising, in 2003, the U.S. Virgin Islands and the states of Nevada and North Dakota against regulating online gaming and when threatening to prosecute media companies advertising for online gambling with aiding and abetting an illegal activity. ${ }^{24}$ In an intriguing twist, however, the DOJ recently revisited its past positions and asserted that the Wire Act only applies to sports betting, as opposed to all forms of internet-based gambling. ${ }^{25}$

\footnotetext{
${ }^{19}$ Cohen, supra note 17.

${ }^{20}$ Arguably the first element of the Wire Act's burden of proof (being engaged in the business of betting or wagering) would be absent; see generally Charles Doyle, Cong. Research Serv., RS21984, Internet Gambling: Overview of Federal Criminal Law (2004); see also United States v. Baborian, 528 F.Supp. 324, 328 (D.R.I. 1981) (excluding individual bettors and social gamblers); United States v. Sellers, 483 F.2d 37, 45 (5th Cir. 1973) (delineating that individual bettors who are "professional gamblers" may be convicted of violating the Wire Act); Cohen v. United States, 378 F.2d 751, 756 (9th Cir. 1967) (remarking that Congress felt that the goal of stopping illegal gambling was better served by imposing duties on those who make gambling their day-to-day business, rather than imposing sanctions on the individual bettor).

${ }^{21}$ In re MasterCard Int'l., 313 F.3d 257 (5 ${ }^{\text {th }}$ Cir. 2002).

${ }^{22} I d$. at 263.

${ }^{23}$ See Gambling Law: An Overview, Cornell U. L. Sch. Legal Info. Inst., http://www.law.cornell. edu/wex/gambling (last visited June 27, 2012).

${ }^{24}$ See Veronica Rose, Legality of Online Poker, State Conn. Gen. Assembly, Off. Legis. Res. Rep. (May 17, 2011), http://www.cga.ct.gov/2011/rpt/2011-R-0229.htm.
}

${ }^{25}$ Virginia Seitz, Whether Proposals by Illinois and New York to Use the Internet and Out-ofState Transaction Processors to Sell Lottery Tickets to In-State Adults Violates the Wire Act, 35 Op. O.L.C. _ (2011), available at http://www.justice.gov/olc/2011/state-lotteries-opinion.pdf; see also Nathan Vardi, Department of Justice Flip-Flops on Internet Gambling, Forbes, Dec. 23, 2011, http://www.forbes.com/sites/nathanvardi/2011/12/23/department-of-justice-flip-flops-oninternet-gambling.

In a further fascinating aspect of this development, the public release of the DOJ opinion took place on December 23, 2011, presumably as a holiday present to industry stakeholders (or alternatively aspiring at less than broad scope publicity by mainstream media outlets in view of the holiday season). In any event, the industry constituents responded very positively (albeit definitely surprised) and remarked that this day would become known as White Friday. 
Indictments for Wire Act violations are usually accompanied by other charges, including conspiracy, money laundering, and violations of the Travel Act of 1961 (Travel Act). ${ }^{26}$ The Travel Act applies to anyone who travels across state borders or uses an interstate facility to promote, attempt, or perform an unlawful activity. ${ }^{27}$ Resembling the Wire Act, the Travel Act only applies to business enterprises engaging in gambling-related transactions, and not casual bettors. ${ }^{28}$ Also in 1961, the Interstate Transportation of Wagering Paraphernalia Act was enacted. ${ }^{29}$ Its purpose was to criminalize the interstate transportation and dissemination of any document, record, media, etc. to be utilized in connection with "bookmaking, wagering pools with respect to sporting events, or numbers . . . or similar game." 30

IIlegal Gambling Business Act of 1970. The Illegal Gambling Business Act ${ }^{31}$ (IGBA) was enacted in 1970, as part of the Organized Crime Control Act. The latter also included the Racketeer Influenced and Corrupt Organizations (RICO) Act. ${ }^{32}$ The IGBA was used by prosecutors in connection with the aforementioned Blue Monday online sports gambling website indictments, as well as others. ${ }^{33}$ The IGBA was particularly aimed at syndicated gambling, federal oversight directed

\footnotetext{
${ }^{26} 18$ U.S.C. $\S 1952(2011)$.

${ }^{27} I d$. (a).

${ }^{28} I d$. (b).

${ }^{29} 18$ U.S.C. § 1953. See, e.g., United States v. Mendelsohn, 896 F.2d 1183 (9th Cir. 1990) (affirming lower court's conviction of defendants who conspired to transport and aided and abetted transportation of wagering paraphernalia by mailing floppy disks with a program entitled Sports Office Accounting Program (SOAP) to aid in bookmaking). But see United States v. Kelly, 328 F.2d 227 (6th Cir. 1964) (discharging defendants who published a newspaper with information on results of sports contests and horseracing, declaring that Congress did not intend to abridge individual rights to issue publications containing racing results and predictions, which were actually also included in existing sections of larger newspaper); United States v. Kish, 303 F. Supp. 1212 (N.D.Ind. 1969) (rendering a "scratch sheet" not enjoying the same protection publications such as newspapers enjoy, given a direct tie to gambling).

${ }^{30}$ Id. (a). See also, H.R. Rep. No. 87-968, 2 (1961), reprinted in 1961 U.S.C.C.A.N. 2634, 2635.

3118 U.S.C. $\$ 1955$.

3218 U.S.C. $\$ 1961$.

${ }^{33}$ See Press Release, U.S. Att'y Office, D.Md., supra note 3. For more sports-related gambling application of IGBA and RICO see Alves v. Player's Edge, Inc., 2007 U.S. Dist. LEXIS 30832 (S.D.Cal 2007) (RICO-only claims failed); United States v. Atiyeh, 402 F.3d 354 (3d Cir. 2005), cert. denied 2005 U.S. LEXIS 9151 (U.S., Dec. 5, 2005); United States v. Iacaboni, 363 F.3d 1 (1st Cir. 2004), cert. denied 543 U.S. 978, 125 S. Ct. 480, 160 L. Ed. 2d 356, 2004 U.S. LEXIS 7417 (2004); United States v. 734,578.82 in United States Currency, 286 F.3d 641 (3d Cir. 2002); United States v. Dote, 150 F. Supp. 2d 935 (N.D.Ill. 2001); State v. Bates, 84 Haw. 211; 933 P.2d 48 (Sup. Ct. Haw. 1997); United States v. Morgano, 39 F.3d 1358 (7th Cir. 1994); United States v. Mauro, 846 F. Supp. 245 (W.D.N.Y. 1994); United States v. Sutera, 933 F.2d 641 (8th Cir. 1991); United States v. Carrozza, 728 F. Supp. 266 (S.D.N.Y. 1990); United States v. Gatto, 750 F. Supp. 664 (D.N.J. 1990); United States v. Cortina, 733 F. Supp. 1195 (N.D.Ill. 1990); United States v. Balistrieri, 779 F.2d 1191 (7th Cir. 1985); United States v. Pepe, 512 F.2d 1129 (3d Cir. 1975).
} 
at individuals operating "gambling businesses of major proportions." ${ }^{4}$ In order to establish a case under the IGBA, the federal government must prove that the gambling operation 1) is violating a state or local law; 2) includes five or more people who finance, manage, supervise, direct, or own all or part of the business; and 3 ) is in substantially continuous activity for more than 30 days or has gross revenue of $\$ 2,000$ or more in any single day. ${ }^{35}$

Racketeer Influenced and Corrupt Organizations Act. The Organized Crime Control Act also included the Racketeer Influenced and Corrupt Organizations (RICO) Act. ${ }^{36}$ The RICO Act became law in 1970 as well, and its purpose was "the elimination of the infiltration of organized crime and racketeering into legitimate organizations operating in interstate commerce." ${ }^{37}$ The statute is sufficiently broad enough to encompass illegal activities relating to any enterprise affecting interstate commerce. For a RICO case to be established, the government needs to prove that an enterprise existed and that it affected interstate or foreign commerce. Next, the accused has to be associated with the enterprise, and participate in the enterprise through a pattern of racketeering activity (including collection of unlawful debts). ${ }^{38}$ The U.S. Supreme Court has held that such a pattern does not require multiple illegal schemes; rather, a pattern is interpreted as both a relationship between the offenses and the continuing threat of such activity. ${ }^{39}$ Lastly, the accused has to participate in the enterprise on his or her free volition. ${ }^{40}$

Unlawful Internet Gambling Enforcement Act of 2006. In the fall of 2006, Congress enacted the Unlawful Internet Gambling Enforcement Act (UIGEA), ${ }^{41}$ which makes it illegal for financial institutions to facilitate payment transactions between offshore gambling operations and American customers. The UIGEA was hurriedly ${ }^{42}$ tacked on to the end of the Security and Accountability for Every Port Act (SAFE Port Act) ${ }^{43}$ The SAFE Port Act was passed by the United States Congress $^{44}$ as the formal legislative response to preempt foreign interests from

\footnotetext{
${ }^{34}$ Syndicated Gambling, U.S. Att'y Manual, Crim. Resource Manual 9-2085, available at http:// www.justice.gov/usao/eousa/foia_reading_room/usam/title9/crm02085.htm (last visited June 9, 2012).

${ }^{35}$ United States v. Sacco, 491 F.2d 995, 998 (9th Cir. 1974).

3618 U.S.C. $\$ 1961$.

${ }^{37}$ S. Rep. No. 91-617, at 76 (1969).

${ }^{38}$ United States v. Joseph, 781 F.2d 549, 555 (6th Cir. 1986) (noting that conspiracy to commit a violation of state gambling laws constitutes racketeering activity).

39 See H.J., Inc. v. Northwestern Bell Tel. Co., 492 U.S. 229, 236-239 (1989).

${ }^{40}$ United States v. Darden, 70 F.3d 1507, 1518 (8th Cir. 1995); see also 31A Am. Jur. 2d Extortion, Blackmail, and Threats $\$ 128$ (1989).

${ }^{41}$ Title VII of SAFE Port Act, 31 U.S.C. § 5361 (2011).

${ }^{42}$ Poker Face Off, Economist (April 20, 2011), available at http://www.economist.com/ node/18586698.

436 U.S.C. $\$ 901$ (2006).

${ }^{44}$ The bill cleared both Houses with practically unanimous approval (unanimous in the Senate and 409-2 in the House, which also passed an earlier version of it by 421-2).
} 
owning and/or operating American seaports as part of the Dubai Ports World controversy. ${ }^{45}$

The UIGEA's preamble explained that new ways to enforce gambling statutes on the internet were necessary. ${ }^{46}$ The UIGEA states: "No person engaged in the business of betting or wagering may knowingly accept [money drawn on U.S. financial institutions] in connection with the participation of another person in unlawful internet gambling." ${ }^{47}$ Prior to the passing of the UIGEA, a customer of an online betting site would be able to personally fund an account through credit cards. The UIGEA calls for regulations that mandate financial transaction providers to implement measures-with respect to certain payment systems that could be used in connection with internet gambling - to identify such prohibited transactions and block them. ${ }^{48}$ The UIGEA does not target individual bettors; instead, it targets the flow of funds to internet gambling operators. ${ }^{49}$

The UIGEA is silent about the legality of the actual use of internet gambling sites by U.S. residents. After considerable discourse, there were clarifications codified in November 2008, setting its effective date as June 1, 2010, and outlining the "prohibition on funding of unlawful internet gambling." 50 It should be noted that the revised UIGEA regulations did not clarify what constitutes unlawful internet gambling. Rather, the regulations purposefully evaded the issue by stating, "a single, regulatory definition of 'unlawful internet gambling' would not be practical."

\footnotetext{
${ }^{45}$ See, e.g., Stephen E. Flynn, The DP World Controversy and the Ongoing Vulnerability of U.S. Seaports, Council on Foreign Rel. (March 2, 2006), available at http://www.cfr.org/port-security/ dp-world-controversy-ongoing-vulnerability-us-seaports-prepared-remarks/p9998; Stephen Zunes, The Dubai Ports World Controversy: Jingoism or Legitimate Concerns?, Foreign Pol'y Focus (March 13, 2006), available at http://www.fpif.org/articles/the_dubai_ports_world_controversy_jingoism_or_legitimate_concerns; After Dubai Ports World, Wash. Post (March 4, 2007), available at http://www.washingtonpost.com/wp-dyn/content/article/2007/03/03/ AR2007030301029.html.
}

4631 U.S.C. $\$ 5361$ (2011).

${ }^{47} I d . \S 5363$.

${ }^{48}$ Financial institutions, banks, and credit card companies would have to, for example, attempt to monitor check and credit card transactions, assign particular codes for unauthorized online gambling, and block such transactions. See generally Lisa Boikess, The Unlawful Internet Gambling Enforcement Act of 2006: The Pitfalls of Prohibition, 12 Legis. \& Pub. Pol'y 151 (2008), available at http://www.law.nyu.edu/ecm_dlv2/groups/public/@nyu_law_website_journals_journal_of_ legislation_and_public_policy/documents/documents/ecm_pro_062194.pdf (recapitulating the several unusual alliances formed in anticipation of UIGEA's adoption and the several competing interests the new law posed for the many stakeholders, qt 167-170).

49 See Charles P. Ciaccio, Internet Gambling: Recent Developments and State of the Law, 25 Berkeley Tech. L. J. 529, 543 (2010) (noting that UIGEA does nothing to clarify what type of internet gambling is unlawful, and does not target "Joe the Gambler"). See also Gerd Alexander, The U.S. on Tilt: Why the Unlawful Internet Gambling Enforcement Act Is A Bad Bet, 5 Duke L. \& Tech. Rev. (2008) available at http://www.law.duke.edu/journals/dltr/articles/2008DLTR0006 (arguing that UIGEA drove away legitimate publicly traded companies whilst resulting in "flyby-night" online gambling companies and third-party processing operations.)

${ }^{50} 12$ CFR $\S 233,31$ CFR $\S 132$ (2008).

${ }^{51} 12$ CFR $\S 233$ at 4. 
The UIGEA includes several exemptions for online fantasy sports, intrastate gambling, interstate horseracing (discussed infra), and gambling governed by Native American gaming regulations. ${ }^{52}$ In addition to the nebulous state of federal gambling provisions, it is important to consider that compliance with federal laws such as UIGEA may still result in violations of state law. ${ }^{53}$ Further, UIGEA has rekindled the discourse for state regulation of internet gambling, given the intricacies and entanglements at the federal level. ${ }^{54}$

After going in to effect in 2010, the UIGEA resulted in almost all of the online gambling industry's publicly listed companies withdrawing from the American market. ${ }^{55}$ The first conviction in a case involving individuals associated with an offshore gambling business occurred on December 5, 2011.56 This was followed shortly thereafter by two guilty pleas in New York by individuals involved in UIGEA-related violations. ${ }^{57}$

\footnotetext{
5231 U.S.C. $\$ 5362$ (2011).

53 Jennifer W. Chiang, Don't Bet on It: How Complying with Federal Internet Gambling Law is Not Enough. 4 Shidler J. L. Com. \& Tech. 2 (2007) (observing that due to lack of cohesive federal oversight states passed internet gambling laws, which regulate making and taking bets online, transferring money between bettor and operator, and even extend to regulating speech and internet casino advertisements).
}

${ }^{54}$ Nicholas M. Wajda, Over-playing a Weak Hand: Why Giving Individual States a Choice is a Better Bet for Internet Gambling in the United States, 29 T. Jefferson L. Rev. 313 (2007) (suggesting that a "superior approach" would be to allow states to regulate internet gambling along the lines of Interstate Horseracing Act provisions, thus allowing states to run interstate gambling operations in conjunction with similarly situated states).

${ }^{55}$ David O. Stewart, Online Gambling Five Years After UIGEA, Am. Gaming Ass'n (2011), available at http://www.americangaming.org/files/aga/uploads/docs/final_online_gambling_ white_paper_5-18-11.pdf; see also Ciaccio, supra note 49, at 543.

${ }^{56}$ Press Release, U.S. Att'y Off., Dist. Mass., Defendants Convicted of Racketeering in Connection with Offshore Gambling Business (Dec. 5, 2011), available at http://www.justice.gov/usao/ma/ news/2011/December/EremianVerdictPR.html. (Daniel and Robert Eremian had built a massive online gambling ring called "Sports Offshore," based in Antigua. They employed approximately 50 gambling agents in the U.S. with hundreds of customers. Prosecutors presented evidence that they laundered more than $\$ 10$ million in checks and wire transfers from 1997 to 2010).

${ }^{57}$ Press Release, U.S. Att'y Off., S.D.N.Y., Director of Payment Processing for Absolute Poker Pleads Guilty in Manhattan Federal Court to Internet Gambling and Fraud Offenses (Dec. 20, 2011), available at http://www.justice.gov/usao/nys/pressreleases/December11/beckleybrentpleapr.pdf; and Press Release, U.S. Att'y Office, S.D.N.Y., Payment Processor for Internet Poker Companies Pleads Guilty in Manhattan Federal Court to Bank Fraud, Money Laundering, and Gambling Offenses (February 12, 2012), available at http://www.justice.gov/usao/nys/pressreleases/February12/langryanpleapr.pdf. 
Other Federal Statutes. A federal statute that also needs to be considered when matters of online betting arise is the Interstate Horseracing Act of 1978, as amended in December of 2000. ${ }^{8}$ What is interesting from this statute is the definition of "interstate off-track wager":

"[I]nterstate off-track wager" means a legal wager placed or accepted in one State with respect to the outcome of a horserace taking place in another State and includes pari-mutuel wagers, where lawful in each State involved, placed or transmitted by an individual in one State via telephone or other electronic media and accepted by an off-track betting system in the same or another State, as well as the combination of any pari-mutuel wagering pools .... . 59

The Interstate Horseracing Act contains explicit provisions on how one can accept an interstate off-track wager online ${ }^{60}$ For example, the consent of the host racing association, host racing regulatory body, and appropriate off-track racing commission are prerequisites to the acceptance of any wager. ${ }^{61}$ Other federal statutes that are utilized in the course of regulating and prosecuting unlawful gambling (and thus may apply in cases where sport betting is conducted) include the 1) Indian Gaming Regulatory Act of 1988, ${ }^{62}$ 2) Illegal Money Transmitting Business Act of 1992, ${ }^{63} 3$ ) Interstate Wagering Amendment of 1994, ${ }^{64} 4$ ) Transportation of Gambling Devices Act of 1951 as amended by the Gambling Devices Act of 1962,65 and 5) Sports Bribery Act of $1964 .{ }^{66}$

\footnotetext{
5815 U.S.C. $\S 3001$ (2012).

5915 U.S.C. $\$ 3002$ (3) (2012).

${ }^{60}$ Nonetheless there has been considerable controversy on whether this statute conflicts with the Wire Act. In his signing statement, President Clinton acknowledged the Justice Department's objection to the amendment: "[S]ection 629 of the Act amends the Interstate Horseracing Act of 1978 to include within the definition of the term 'interstate off-track wager,' pari-mutuel wagers on horseraces that are placed or transmitted from individuals in one State via the telephone or other electronic media and accepted by an off-track betting system in the same or another State. The Department of Justice, however, does not view this provision as codifying the legality of common pool wagering and interstate account wagering even where such wagering is legal in the various States involved for horseracing, nor does the Department view the provision as repealing or amending existing criminal statutes that may be applicable to such activity, in particular, sections 1084, 1952 and 1955 of Title 18, United States Code." 5 U.S. Code \& Cong. News., 106th Cong. 2nd Sess., 2457-2458 (2000); see also Jeffrey R. Rodefer, Internet Gambling in Nevada: Overview of Federal Law Affecting Assembly Bill 466, 6 Gaming L. Rev. 393 (2004), Ciaccio, supra note 49.
}
61 15 U.S.C. $\S 3004$ (2011)
6225 U.S.C. $\$ 2701$ (2012).
6318 U.S.C. $\$ 1960$ (2011).
${ }^{64} 18$ U.S.C. $\$ 1301$ (2012).
6515 U.S.C. $\$ 1171$ (2012).
6618 U.S.C. $\S 224$ (2012). 


\section{Overview of State Laws}

It is important to note that federal law does not address the hotly debated "skill vs. luck" issue, which is especially relevant in fantasy sports ${ }^{67}$ and poker. ${ }^{68}$ In Humphrey v. Viacom, a plaintiff attempted to apply state qui tam statutes for the recovery of gambling proceeds from major media conglomerates operating pay-for-play fantasy sports leagues online. Qui tam laws, when applied to gambling, are intended to protect gamblers' families from becoming destitute due to one's gambling addiction by allowing for recovery of gambling losses when such a situation can be proven. ${ }^{69}$ The plaintiff in Humphrey v. Viacom engaged in an educational effort on common law and New Jersey qui tam law's application in gambling cases. However, his effort was unsuccessful in both the qui tam application and in arguing that fantasy sports were a form of gambling.

Iowa, second only to the efforts from New Jersey (analyzed in detail infra), featured legislation that would challenge the federal ban on sport betting. However, that state legislative effort failed in $2010 .^{70}$ The District of Columbia and 47 states (Alaska, Hawaii, and Utah are the outliers) allow lotteries, casinos, and/

\footnotetext{
${ }^{67}$ Humphrey v. Viacom, 2007 U.S. Dist. LEXIS 44679, 2007 WL 1797648 (D.N.J. 2007).

${ }^{68}$ See, e.g., Pennsylvania v. Dent, 992 A.2d 190 (Pa. Super. 2010); Joseph M. Kelly, Zeeshan Dhar, \& Thibault Verbiest, Poker and the Law: Is It a Game of Skill or Chance and Legally Does It Matter?, 11 Gaming L. Rev. 190 (2007) (presenting a comparative examination of international jurisdictions' gambling laws, finding several where poker is treated as a game of skill, and arguing that there is considerable tax revenue to be generated by such treatment); Ulf Johansson, Cecilia Sonstrod, \& Lars Niklasson, Explaining Winning Poker - A Data Mining Approach, 6th International Conference on Machine Learning and Applications, Orlando, FL, IEEE press, 129134 (2006) (investigating a dataset of 105 players over 500 hands each in short-handed small stakes Texas Hold 'em, and attempting to draw inferences of successful play; this particular study established suggested techniques consistent with poker theory and argues that with more data available in the future further descriptions of set parameters may be established delineating between successful and unsuccessful poker).

${ }^{69}$ Humphrey v. Viacom, supra note 67, at 4 . The broader meaning of qui tam laws is that a private party is allowed standing and may bring forth action on behalf of the government (e.g. via whistleblower statutes) and may even recover damages emanating from such action. A more complete description of the term in Latin is "qui tam pro domino rege quam pro se imposo sequitur", interpreted as "one who brings the action for the king and for oneself." Bass Anglers Sportsman's Soc'y of Am. v. U.S. Plywood-Champion Papers, Inc., 324 F.Supp. 302, 305 (S.D. Tex. 1971).

70 The Iowa's Senate bill was S.B. 2129. See Gambling Developments in the States, 2010, Nat'1 Conf. St. Legislatures (NCSL), http://www.ncsl.org/issues-research/econ/gambling-developmentsin-the-states-2010.aspx (last visited April 14, 2012); see also Intrastate Online Gambling Gould Make Iowa up to \$13 Million Yearly: Study, Gazette, http://thegazette.com/tag/iowa-racing-andgaming-commission (last visited April 14, 2012) (SF 2129 and 2214, a successor bill to SF 2129, would have allowed sports betting to be legal in state licensed gambling venues if PASPA was overturned either through federal law or by a challenge in court. Amateur and professional sports betting would have been allowed under SF 2129 while only professional sports betting would be allowed under SF 2214. Both legislative bills passed out of the Iowa Senate State Government Committee).
} 
or pari-mutuel gaming, such as horse racing. ${ }^{71}$ Alaska allows charitable gaming, social gambling, and select other forms of gambling in the state's casinos. Hawaii only allows social gambling. ${ }^{72}$ Utah, where one finds the most stringent U.S. state gambling policy, does not allow any gambling as declared by the state's Constitution in Article VI, Legislative Department Section 27, under the heading "Games of Chance not authorized." 73 In a technology-specific move, the states of Illinois, Indiana, Louisiana, Montana, Nevada, Oregon, South Dakota, Wisconsin, and Washington State have all recently passed legislation that specifically prohibits unauthorized forms of internet gambling. ${ }^{74}$

Washington State, in particular, appears to be exceptionally harsh, as it characterizes someone who bets online as committing a class $\mathrm{C}$ felony, similarly to third-degree statutory rape. ${ }^{75}$ Washington also featured a unique case, Internet Community v. Washington, in which an online business, Betcha.com, provided a stock exchange-like platform connecting individuals on a person-to-person basis. ${ }^{76}$ Bets therein included sporting bets, political results, and pop culture entertainment. The Betcha.com twist was that bettors who lost could have opted not to pay within 72 hours. If they selected to forego payment, the only repercussion was that they ran the risk of receiving a low online evaluation and score poorly in an "honor rating" system. The Washington State Supreme Court reversed a lower court decision holding that Betcha.com was not running a gambling business, as bettors "did not have an understanding that they 'will' receive something of value, only that they might, if the losing bettor decided to actually honor the bet." 77 The state Supreme Court held that

\footnotetext{
${ }^{71}$ Factsheet: Types of Gaming by State, Am. Gaming Ass'n, http://www.americangaming.org/ industry-resources/research/fact-sheets/states-gaming (last visited April 14, 2012); see also Gambling in the United States, NCSL, http://www.ncsl.org/issues-research/econ/gambling-inthe-united-states.aspx (last visited April 14, 2012). The NCSL, at least bi-annually, compiles state legislative summaries on gambling policy developments and makes them available at http:// www.ncsl.org/issues-research.aspx ?tabs $=951,63,490 \# 490$, with the most recent ones available at http://www.ncsl.org/issues-research/econ/gambling-developments-in-the-states-2010.aspx.

72 Chuck Humphrey, Summary Chart, St. Gambling L. Summary, http://www.gambling-law-us. com/State-Law-Summary (last visited April 16, 2012). A bill (H.B. 2251) that would have created the first Hawaii-based casino failed in 2010, NCSL, supra note 70.

${ }^{73}$ Utah Const. art. VI, sec. 27, avalable at http://le.utah.gov/ code/const/htm/00I06_002700.htm.

${ }^{74}$ Humphrey, supra note 72.

${ }^{75}$ See Ciaccio, supra note 49, at 549, n. 146. Compare Wash. Rev. Code Ann. § 9.46.240 (West 2009) (internet gambling) with Wash. Rev. Code Ann. § 9A.44.060 (West 2009) (third-degree rape); Class $\mathrm{C}$ felonies carry a maximum sentence of five years and a maximum fine of ten thousand dollars. Wash. Rev. Code Ann. § 9A.20.021 (West 2009).

${ }^{76}$ Internet Cmty \& Entm't. Corp. v. Washington State Gambling Comm'n, 2010 WL 3432595 (Wash. Supreme Ct. Sept. 2, 2010).

${ }^{77}$ Internet Cmty \& Entm’t Corp. v. State, 201 P.3d 1045 (Wash. Ct. App. 2009).
} 
Betcha was engaged in professional gambling because it engaged in 'bookmaking' as that term is defined under the gambling act. Based on this conclusion ... Betcha transmitted 'gambling information' and used 'gambling records' as part of its business. ${ }^{78}$

In general, owning an online gaming operation without proper licensing would be illegal, as no states are currently granting interstate online gaming licenses. Presumably, with the change of stance from the DOJ on the Wire Act's scope and its inapplicability with online (non-sports) gambling ${ }^{79}$ one can reasonably foresee more states riding the wave of online gambling regulation in the near future. ${ }^{80}$

\section{The Professional and Amateur Sports Protection Act (PASPA)}

\section{Legislative History}

Senate bill 474 was introduced in the $102^{\text {nd }}$ session of Congress on February 22, 1991 by Senator Dennis DeConcini [D-AZ] and signed into law by President George H. W. Bush on October 28, 1992. ${ }^{81}$ PASPA's intended purpose was to "prohibit sports gambling conducted by, or authorized under the law of, any State or other governmental entity." ${ }^{82}$ Congress concluded that sports wagering was ". . . undermin[ing] public confidence in the character of professional and amateur sports," as well as “. . promot[ing] gambling among our Nation's young people." 83 Thus PASPA

represents a judgment that sports gambling . . . is a problem of legitimate Federal concern for which a Federal solution is warranted .... We must do everything we can to keep sports clean so that the fans, and especially young people, can continue to have complete confidence in the honesty of the players and the contests. ${ }^{84}$

Prior to the passing of PASPA there was a considerable lobbying effort by Major League Baseball (MLB) and other professional and amateur sports' stakeholders. ${ }^{85}$

\footnotetext{
${ }^{78}$ Internet Cmty \& Entm't Corp. v. Washington State Gambling Comm'n, 2010 WL 3432595, at IV (Wash. Supreme Ct. 2010).

${ }^{79}$ Wire Act, supra notes 14 and 20 and accompanying text.

${ }^{80}$ Already several states have moved toward online gambling regulation. See generally Safe and Secure Internet Gambling Initiative, http://www.safeandsecureig.org/content/news (last visited April 16, 2012); Humphrey, supra note 72, and NCSL, supra note 71.

8128 U.S.C. $\$ 3701$ (1992).

${ }^{82}$ S. Rep. No. 102-248 (1992), at 3.

${ }^{83} \mathrm{Id}$. at $4-7$.

${ }^{84} \mathrm{Id}$.

${ }^{85}$ Ryan M. Rodenberg, U.S. Sport's Opposition to Betting: Potential for Change, 10 World Sports L. Rep. 12 (2012).
} 
Importantly, there was a very strong constituency for PASPA led by former New Jersey U.S. Senator and professional basketball player Bill Bradley, a vocal critic of sports betting. After describing his first-hand observation regarding the negative impact of sport gambling, ${ }^{86}$ Senator Bradley proffered several reasons behind his support of PASPA:

Athletes are not roulette chips, but sports gambling treats them as such. If the dangers of state sponsored sports betting are not confronted, the character of sports and youngsters' view of them could be seriously threatened . . . just as legalizing drugs would lead to increased drug addiction, legalizing sports gambling would aggravate the problems associated with gambling. As a society, we cannot afford this result, and ... legalizing sports gambling would encourage young people to participate in sports to win money. They would no longer love the game for the purity of the experience. ${ }^{87}$

There were a few important procedural developments around PASPA, which are certain to come to the fore in impending litigation challenging its constitutionality. First, a document referred to as a "smoking gun" by plaintiffs in recent PASPA's challenges, ${ }^{88}$ was the DOJ's letter to then-U.S. Senator Joe Biden. ${ }^{89}$ In this letter, Assistant Attorney General W. Lee Rawls generally posited that the Wire Act would serve as sufficient deterrent against interstate sports gambling, while also raising three major concerns about the draft legislation: 1) Congress generally defers to the states in respect to revenue generation, 2) federalism, and 3) a "particularly troubling" finding that sports organizations are permitted to enforce PASPA's provisions. ${ }^{90}$

\footnotetext{
${ }^{86}$ Bradley's contention that he had witnessed fans cheering a seemingly irrelevant NBA end of game shot that resulted in a team covering the spread was not confirmed or pinpointed to a particular game by Bradley himself. See generally Larry Josephson, Righting a Wrong: A History in New Jersey Sports Betting, Covers, http://www.covers.com/articles/articles.aspx?theArt=251825 (last visited April 16, 2012).

${ }^{87}$ Bill Bradley, The Professional and Amateur Sports Protection Act-Policy Concerns Behind Senate Bill 474, 2 Seton Hall J. Sport L. 5, 5-7 (1992).

${ }^{88}$ Interactive Media Entm't. \& Gaming Ass'n, Inc. v. Holder, 2011 WL 802106 (D.N.J. 2011) (No. 09-1301).

${ }^{89}$ Letter from Assistant Att'y Gen. W. Lee Rawls to Sen. Joseph R. Biden, Jr. (Sept. 24, 1991), available at http://www.federalgaminglaw.com/page18/files/PASPAletters_DOJ_Senate91.pdf. The authors wish to thank an anonymous reviewer who pointed out the fact that then-Chairman of the Senate's Judiciary Committee, Vice President Joe Biden, was previously a long-serving U.S. Senator from Delaware, one of the exempt states in the final version of PASPA in 1992.

${ }^{90} \mathrm{Id}$.
} 
PASPA contained some significant exemptions, ${ }^{91}$ by which certain states' thenexisting sport gambling systems would be grandfathered into the new legislative framework. Hence, the states of Delaware, Montana, Nevada, and Oregon were essentially granted preferential treatment. Relatedly, the statute granted New Jersey, and only New Jersey, the opportunity to enact sport betting within one year from PASPA's effective date. However, the one-year window for New Jersey closed with no legislative action for a variety of reasons. ${ }^{92}$

\section{Statutory Text of PASPA}

PASPA's text is concise:

\section{It shall be unlawful for-}

1. a governmental entity to sponsor, operate, advertise, promote, license, or authorize by law or compact, or

2. a person to sponsor, operate, advertise, or promote, pursuant to the law or compact of a governmental entity, a lottery, sweepstakes, or other betting, gambling, or wagering scheme based, directly or indirectly (through the use of geographical references or otherwise), on one or more competitive games in which amateur or professional athletes participate, or are intended to participate, or on one or more performances of such athletes in such games. ${ }^{93}$

A civil action to enjoin a violation of section 3702 may be commenced in an appropriate district court of the United States by the Attorney General of the United States, or by a professional sports organization or amateur sports organization whose competitive game is alleged to be the basis of such violation. ${ }^{94}$

9128 U.S.C. § 3704: (a) Section 3702 shall not apply to-(1) a lottery, sweepstakes, or other betting, gambling, or wagering scheme in operation in a State or other governmental entity, to the extent that the scheme was conducted by that State or other governmental entity at any time during the period beginning January 1, 1976, and ending August 31, 1990; (2) a lottery, sweepstakes, or other betting, gambling, or wagering scheme in operation in a State or other governmental entity where both-- (A) such scheme was authorized by a statute as in effect on October 2, 1991; and $(B)$ a scheme described in section 3702 (other than one based on parimutuel animal racing or jai-alai games) actually was conducted in that State or other governmental entity at any time during the period beginning September 1, 1989, and ending October 2, 1991, pursuant to the law of that State or other governmental entity; [The above exceptions applied to the four states grandfathered in, namely Delaware, Montana, Nevada, and Oregon. The exception below under (3) is the one that allowed New Jersey to consider being the fifth state to survive the new restrictive regulatory scheme after January $1^{\text {st }} 1993$.] (3) a betting, gambling, or wagering scheme, other than a lottery described in paragraph (1), conducted exclusively in casinos located in a municipality, but only to the extent that-- (A) such scheme or a similar scheme was authorized, not later than one year after the effective date of this chapter, to be operated in that municipality; and $(B)$ any commercial casino gaming scheme was in operation in such municipality throughout the 10-year period ending on such effective date pursuant to a comprehensive system of State regulation authorized by that State's constitution and applicable solely to such municipality; or (4) parimutuel animal racing or jai-alai games.

${ }^{92}$ See Josephson, supra note 86.

9328 U.S.C. $\$ 3702$ (2012).

${ }^{94} I d . \S 3703$. 


\section{Litigation Inolving PASPA}

Major League Baseball, et al v. Markell (2009 Delaware Case). PASPA included several exemptions for states with some form of sport betting regulated before it was passed. Whereas Oregon felt compelled to discontinue its "Sports Action" sports lottery under pressure from the NCAA, ${ }^{95}$ Montana and Nevada continued their regulated sport gambling practices. However, the most entrepreneurial and corporate-friendly state, Delaware, ${ }^{96}$ engaged in a long history of legal battles with sport leagues over sport betting. ${ }^{97}$

In 2009, Delaware passed an act that would regulate single-game wagers on professional and amateur sporting contests. ${ }^{98}$ In unison, the four major North American team sports leagues [MLB, National Football League (NFL), National Basketball Association (NBA), and National Hockey League (NHL)] and the National Collegiate Athletic Association promptly filed suit seeking an injunction that would bar any such broadening of Delaware's traditional football parlay sport betting scheme. ${ }^{99}$ Delaware's interpretation was arguably testing the limits of PASPA's exemption under 28 U.S.C. $\$ 3704(\mathrm{a})(1),{ }^{100}$ by claiming that the plain language of PASPA allows the state to "reintroduce a sports lottery under State control because Delaware conducted such a scheme at some time between January 1, 1976, and August 31, 1990." ${ }^{101}$ The Third Circuit focused the analysis on $\S$ 3704(a)(2), and agreed with the leagues' contention that PASPA's exemptions should be narrowly tailored to betting schemes that were actually conducted in the protected period. ${ }^{102}$ The Third Circuit also disagreed with Delaware's somewhat

\footnotetext{
${ }^{95}$ See John Hunt, Betting on March Madness Payoff, Oregonian (Feb. 25, 2009), available at http:// www.oregonlive.com/collegebasketball/index.ssf/2009/02/betting_on_march_madness_payof. $\mathrm{html}$ (documenting the state's move to discontinue its sports lottery, an action that was criticized by economists as the consistent revenue from the lottery was arguably being substituted by uncertain economic benefits through occasional NCAA events; David D. Waddel \& Douglas L. Minke, Why Doesn't Every Casino Have a Sports Book?, Global Gaming Bus. (July 9, 2008) available at http://www.ggbmagazine.com/articles/Why Doesn't_Every Casino Have a Sports -Book_(summarizing federal and state law developments in view of PASPA challenges); Thomas L. Skinner III, The Pendulum Swings: Commerce Clause and Tenth Amendment Challenges to PASPA, 2 UNLV Gaming L. J. 311, 312 (2011) (establishing unconstitutionality grounds and forecasting possible challenges against PASPA's alleged overreach in states' affairs.

${ }^{96}$ With more than 900,000 companies, two-thirds of the Fortune 500, and more than half of US publicly-traded companies, Delaware is broadly acknowledged as the most desirable state to set-up a business. See generally Delaware Dep't St., Division of Corp., http://corp.delaware.gov (last visited April 16, 2012); Lewis S. Black, Jr., Why Corporations choose Delaware, Delaware Dep't St., Division of Corp. (2007), available at http://corp.delaware.gov/whycorporations_web.pdf.

${ }^{97}$ NFL v. Delaware, 435 F. Supp. 1372 (D. Del. 1977); MLB, et al v. Markell, 579 F.3d 293 (3d. Cir. 2009). As a result of the latter case, Delaware is restricted to offering football betting using multi-game parlay cards only.

${ }^{98}$ MLB, 579 F.3d at 295-6.

${ }^{99} \mathrm{Id}$.

${ }^{100} I d$.

${ }^{101} I d$. at 301.

${ }^{102} I d$.
} 
tentative assertion that Congress meant to conflate "authorized" with "conducted". 103 The Court also disagreed with Delaware's alternative assertion, the application of another exemption in PASPA $\S 3704$ (a)(3), which dealt with casinos. Namely, the court held that the particular exception differs in subject matter, structure, and syntax from the language of $\S 3704(\mathrm{a})(1){ }^{104}$

Interestingly, a key difference between the Delaware case and the litigation moved by New Jersey stakeholders and the Interactive Media Entertainment and Gaming Association (IMEGA), ${ }^{105}$ was that Delaware did not challenge PASPA's constitutionality explicitly. As with Nevada's monopoly preservation interests arguably expressed through lobbying for New Jersey's status quo in 1993, ${ }^{106}$ Delaware similarly would have some market share/potential to lose if surrounding states would be able to also offer some form of sport gambling in the near future. ${ }^{107}$ Hence, the U.S. Court of Appeals for the Third Circuit found "unpersuasive Delaware's argument that its sovereign status requires that it be permitted to implement its proposed betting scheme." 108 Finally, Delaware also failed in attempting to convince the Third Circuit that narrowly interpreting PASPA's exception and application to Delaware's scheme would render PASPA's exception a nullity. Therein, the Third Circuit assumed a somewhat common sense approach and allowed minor deviations, as long as the sport betting scheme was in the spirit and concept close to the originally exempt from PASPA coverage of the Delaware sport gambling system. ${ }^{109}$ On May 3, 2010 the case ended subsequent to the U.S. Supreme Court denying Delaware's petition for writ of certiorari. ${ }^{110}$

IMEGA v Holder (2011 New Jersey Case). It would not appear surprising to the careful observer of sport gambling issues that the site where PASPA would come full circle to the state of New Jersey. After all, it was the state of New Jersey that could have been the fifth jurisdiction grandfathered in by PASPA as mentioned above. On March 23, 2009, IMEGA, a New Jersey-incorporated trade association representing several internet gambling and other online entertainment gaming

${ }^{103} I d$

${ }^{104}$ Id. at 302.

105 See Interactive Media Entm’t \& Gaming Ass’n, 2011 WL 802106.

106 See Josephson, supra note 86 and accompanying text; see also Aaron J. Slavin, The "Las Vegas Loophole" and the Current Push in Congress Towards a Blanket Prohibition on Collegiate Sports Gambling, 10 U. Miami Bus. L. Rev. 715 (2002).

107 See NFL, 435 F. Supp. 1372, and MLB, 579 F.3d 293.

${ }^{108}$ MLB, 579 F.3d at 303.

109 Id. at 303-304.

110 Markell v. MLB, cert denied, 130 S.Ct. 2403 (2010). It is useful to observe petitioners' contentions and a slight shift in strategy preparing the U.S. Supreme Court case. The two reasons promulgated for granting review and reversing the Third Circuit's decision were: (i) the Third Circuit erred in concluding that Congress has prohibited Delaware from adopting a sports lottery scheme that meets its revenue-generating needs and (ii) the Third Circuit erred in deciding on the merits whilst reviewing a preliminary injunction. Petition for writ of certiorari filed, Jan. 27, 2010 (No. 09-914), available at http://www.scotusblog.com/wp-content/ uploads/2010/04/09-914_pet.pdf. 
properties, and several other interested parties ${ }^{111}$ filed suit again against U.S. Attorney General Eric Holder, U.S. Attorney for the District of New Jersey Ralph Marra, and an unidentified number of professional and amateur sport organizations.

The complaint was filed in the U.S. District Court for the District of New Jersey and sought to declare PASPA invalid and void. ${ }^{112}$ The plaintiffs utilized nine claims in their efforts to render PASPA illegal and unenforceable. These nine claims alleged that PASPA

1. Violated the U.S. Constitution's Commerce Clause. Article I, Section 8, Clause 3 of the U.S. Constitution provides for Congress to regulate commerce with foreign nations, among the several states, and with Indian tribes. Under the Commerce Clause, Congress needs to pursue uniform legislation among the states, as opposed to PASPA allowing four states' sport betting schemes; namely, the plaintiffs alleged that the four states exempt from PASPA's prohibition of sport gambling were receiving preferential treatment in violation of the Commerce Clause

2. Violated the Fourteenth Amendment of the U.S. Constitution, upholding equal treatment of all citizens, by granting rights and privileges to residents of four states that the other 46 states' citizens would be unable to enjoy. Thus, PASPA was argued to be unconstitutional, violating the Fourteenth Amendment

3. Was vague and overbroad, thus violating both the Fifth and Fourteenth Amendment of the U.S. Constitution, not granting certain states' citizens rights of due process

4. Violated the Tenth Amendment to the U.S. Constitution, by which states reserve the right to regulate their affairs if they do not fall within the auspices of the enumerated powers of the federal government. As such, sport betting, whence revenue generation for each state may be pursued, is not among those enumerated powers, thus Congress should not abridge states' constitutional rights

5. Violated the Eleventh Amendment to the U.S. Constitution, by which the judicial power of the United States shall not be construed to extend to any suit in law or equity, commenced or prosecuted against one of the states by citizens of another state or citizens or subjects of a foreign state. Specifically, the state of New Jersey did not waive its sovereign immunity. PASPA further violated the Eleventh Amendment according to the plaintiffs by allowing sport organizations to prosecute alleged PASPA violations

6. Violated Senator Lesniak's First Amendment rights and particularly his right to legislate freely

7. Violated Plaintiffs' rights to procedural due process under the Fourth, Fifth, and Fourteenth Amendments, as they would be unable to defend themselves, argue for their actions, and challenge PASPA's enforcement and prosecution by sports organizations

8. Violated Plaintiffs' rights to substantive due process under the Fourth, Fifth, and Fourteenth Amendments, once again by discriminating among residents

\footnotetext{
${ }^{111}$ A horse racing trade group and New Jersey State Senators Raymond Lesniak and Stephen Sweeney were co-plaintiffs.

${ }^{112}$ See Interactive Media Entm't \& Gaming Ass'n, 2011 WL 802106.
} 
of certain states and denying certain states' citizens' rights to freely engage in sport betting activity and internet utilization activities

9. Violated Plaintiffs' constitutional rights to privacy by abridging their use of the internet and available sport betting services. ${ }^{113}$

On March 7, 2011, in a decision delivered by U.S. District Court Judge Garrett Brown, the plaintiffs' complaint was dismissed for lack of standing. Because at the time of the decision there was no legislative output, neither actual inclusion of the Governor nor the people of New Jersey with evident interest (presumably subsequent to a referendum, and in view of legislative progress following such a policy direction as would have been expressed by the people of New Jersey), the court concluded that

... [T]hese Plaintiffs have not satisfied the injury and redressability requirements for standing. Beginning with Plaintiffs' argument that they have suffered an injury, because PASPA exposes them to liability for promoting sports betting 'and its adoption in the State of New Jersey' ... the Court finds that these Plaintiffs have not alleged an actual or imminent injury. ${ }^{114}$

Moreover, "the threat of a civil enforcement action at this juncture is just as speculative as Plaintiffs' forecast that the voters will pass SCR 132 and the legislature will subsequently authorize sports gambling through legislation." 115 Judge Brown declared: "If PASPA were found unconstitutional, New Jersey law would still prohibit the sports gambling activities Plaintiffs and their members seek to legalize" 116 and "[b]ecause the State has not intervened in this suit, Plaintiffs lack standing to present a Tenth Amendment claim." 117

In essence, Judge Brown instructed the plaintiffs on the process by which New Jersey stakeholders and industry constituents (pursuant to state legislative action) would be found to have standing, based on his decision parameters. Indeed, this March 2011 decision commenced a grassroots effort and state-wide preparation for a referendum to be included on the November 2011 election ballot. By this referendum, the New Jersey legislature would decide directions for sport betting regulation, and thereafter rekindle the pertinent federal challenge against PASPA. The text of the public question was as follows:

Shall the amendment to Article IV, Section VII, paragraph 2 of the Constitution of the State of New Jersey, agreed to by the Legislature, providing that it shall be lawful for the Legislature to authorize by law wagering at casinos or gambling houses in Atlantic City and at current or former running and harness horse racetracks on the results of professional, certain college, or amateur sport or athletic events, be approved? ${ }^{118}$

\footnotetext{
${ }^{113} I d$.

${ }^{114} I d$.

${ }^{115} I d$.

${ }^{116} I d$.

${ }^{117} I d$.

118 S. Con. Res. 49, 214th Leg., Reg. Sess. (N.J. 2011), available at http://www.njleg.state. nj.us/2010/Bills/SCR/49_I1.PDF.
} 
The final result of the ballot measure election indicated New Jersey voters were in support of the resolution, with $64 \%$ voting in favor. ${ }^{119}$ Shortly after the referendum results, the New Jersey legislature proceeded with passing the pertinent legislative amendment. ${ }^{120}$ In 2012, nineteen years after PASPA's enactment, New Jersey Governor Christie signed bill S3113 into law that would allow sport betting to take place in New Jersey casinos and racetracks. ${ }^{121}$ Thus, a new round of litigation challenging PASPA in federal courts is almost certain in the immediate future.

\section{Corruption Considerations}

As discussed in detail supra, competitive integrity preservation and the prevention of corruption in sporting contests were major tenets in furtherance of PASPA's enactment in 1992. ${ }^{122}$ An appeal to economics-based corruption research helps explain the impetus for PASPA and shapes the contemporary debate about PASPA's continuing viability in an internet-heavy environment. Anti-corruption efforts through policymaking have been studied in-depth in the non-sport economics literature, where the deleterious impact of corruption has been analyzed from both a macroand micro-level. ${ }^{123}$ At the macro-level, empirical evidence has shown corruption to facilitate poverty-causing income inequality, ${ }^{124}$ decreased firm growth, ${ }^{125}$ and lower investment. ${ }^{126}$ Corruption has been modeled as a function of multiple equilibriums dependent on the number of honest and dishonest individuals, ${ }^{127}$ differences among

119 For a full recap of the vote and related information, see New Jersey Sports Betting Amendment, Public Question 1, Ballotpedia (2011), available at http://ballotpedia.org/wiki/index.php/ New_Jersey_Sports_Betting_Amendment,_Public_Question_1_(2011).

${ }^{120}$ S. 3113, 214th Leg., Reg Sess., (N.J. 2011) available at http://www.njleg.state.nj.us/2010/ Bills/S3500/3113_I1.PDF.

${ }^{121}$ Christie Signs NJ Sports Betting Bill Into Law, CBS News Money Watch (January 18, 2012), http://www.cbsnews.com/8301-505245_162-57360885/christie-signs-nj-sports-betting-bill-intolaw; see also Matt Friedman, Gov. Christie Signs Bill Allowing Gamblers to Place Bets on Pro, College Sports Teams, New Jersey Real-Time News (January 17, 2012), available at http://www. nj.com/news/index.ssf/2012/01/gov_christie_signs_bill_allowi_4.html.

122 The issue of corruption in sport is relevant outside the USA as well. For a comprehensive overview of such issues from a non-American perspective, see M. Morgan \& S. Shevill, Integrity: Tackling Sporting Fraud, World Sports Law Report (forthcoming 2012).

${ }^{123}$ Interestingly, early non-empirical research posited that corruption may enhance efficiency and provide "grease" to the wheels of commerce. See Nathaniel H. Leff, Economic Development through Bureaucratic Corruption, 8 Am. Behav. Sci. 8 (1964).

124 Sanjeev Gupta et al., Does Corruption Affect Income Inequality and Poverty, 3 Econ. Governance 23 (2002).

${ }^{125}$ Raymond Fisman \& Jakob Svensson, Are Corruption and Taxation Really Harmful to Growth? Firm Level Evidence, 83 J. Dev. Econ. 63 (2007).

126 Pierre-Guillaume Meon \& Khalid Sekkat, Does Corruption Grease or Sand the Wheels of Growth?, 122 Pub. Choice 69 (2005).

127 Pranab Bardhan, Corruption and Development: A Review of Issues, 35 J. Econ. Literature 1320 (1997). 
cultures, ${ }^{128}$ uncertainty among actors, ${ }^{129}$ and regulatory institutions and procedures. ${ }^{130}$ Anti-corruption efforts in response have been shown to fail on the basis of vulnerabilities in the principal-agent model, ${ }^{131}$ the collective action problem, ${ }^{132}$ and gaps between reality and design. ${ }^{133}$

The preceding summary culled from economic-based research outside of sports evidences why league governing bodies and lawmakers alike have expressed concern over the negative impact gambling-related corruption can have in competitive sports. The pernicious effect of corruption has, in turn, been examined in sports gambling markets, an industry with abundant data, making it a favorable context to test corruption-related theories empirically. Micro-focused corruption studies take a number of forms, including indirect forensic approaches that compare actual secondary data with predictions based on statistical models and economic theory. ${ }^{134}$ This approach has specifically been employed in a number of sports gambling-specific research papers. The most prominent example pertained to purported point shaving in men's college basketball and received widespread media attention upon publication in 2006. ${ }^{135}$ Citing the incentives for gambling-related corruption that derive from the structure of basketball betting where heavy favorites ${ }^{136}$ can win the game outright but fail to cover the point spread in furtherance of wagers on the underdog team, the author concludes that there is a prima facie case of $6 \%$ of all games featuring a strong favorite to be corrupted by gambling-related point shaving. ${ }^{137}$ Although prominent, this illustrative example in the context of college basketball exposed the potential weaknesses of the "forensic" approach where findings are sensitive to assumptions and model specification, as the study has been refuted, ${ }^{138}$

\footnotetext{
${ }^{128}$ Abigail Barr \& Danila Serra, Corruption and Culture: An Experimental Analysis, 94 J. Pub. Econ. 862 (2010).
}

${ }^{129}$ Dmitry Ryvkin \& Danila Serra, How Corruptible Are You? Bribery Under Uncertainty, 81 J. Econ. Behav. \& Org. 466 (2012).

130 Anthony Ogus, Corruption and Regulatory Structures, 36 Law \& Pol'y 329 (2004).

${ }^{131}$ Gary S. Becker \& George J. Stigler, Law Enforcement, Malfeasance, and Compensation of Enforcers. 1 J. Legal Stud. 1 (1974).

132 Anna Persson et al., The Failure of Anti-Corruption Policies: A Theoretical Mischaracterization of the Problem, (University of Gothenburg Quality of Government Institute, Working Paper, 2010), available at http://www.sida.se/PageFiles/39460/Failure\%20Anti_Corruption\%20 policy\%20(2).pdf.

${ }^{133}$ Richard Heeks \& Harald Mathisen, Understanding Success and Failure of Anti-Corruption Initiatives, Crime, Law \& Soc. Change (forthcoming 2012).

${ }^{134}$ Eric Zitzewitz, Forensic Economics, J. Econ. Literature (forthcoming 2012), available at http:// www.dartmouth.edu/ ericz/forensic.pdf.

135 Justin Wolfers, Point Shaving: Corruption in NCAA Basketball, 96 Am. Econ. Rev. 279 (2006).

${ }^{136}$ Wolfers describes heavy favorites as "those favored to win by more than 12 points." Id. at 280.

137 This figure is equal to 500 games, or $1 \%$ of the entire sample culled over the course of the author's 16 year data set. $I d$. at 283 . Point shaving in college basketball was modeled generally as well. See Yang-Ming Chang \& Shane Sanders, Corruption on the Court: Social Consequences of Point Shaving in College Basketball, 5 Rev. L. \& Econ. 269 (2009).

${ }^{138}$ Neal Johnson, NCAA “Point Shaving” as an Artifact of the Regression Effect and the Lack of Tie Games, 10 J. Sports Econ. 59 (2009). 
distinguished, ${ }^{139}$ and alternatively explained. ${ }^{140}$ Nevertheless, the impact of gambling-related corruption on sport is profound, ${ }^{141}$ meriting the attention of policymakers, sports leagues, bookmakers, and individual gamblers.

The technological shock of the internet, popularized shortly after PASPA enactment, has revolutionized the sports gambling industry. ${ }^{142}$ Prior to the internet, the domestic market for American sports bettors was limited to two options: legal wagering in Nevada or illegal wagering with a neighborhood bookie. The internet has largely removed geographic constraints. The landscape now includes regulated "brick and mortar" sports books like those throughout Nevada, thousands of illegal bookies operating around the country, internet sports books physically located outside the United States. ${ }^{143}$ As a result, regulated betting exchanges such at Betfair seemingly operate like a stock exchange and offer a multitude of "real-time" options for sports bettors, and a seemingly novel vehicle that operates as a quasi-hedge fund. ${ }^{144}$ The breadth of options has given rise to price discrimination, dispersion of monopoly power, and significant market differentiation. ${ }^{145}$ Reduced barriers to entry and more transparent pricing have also emerged. ${ }^{146}$ The technologicallydriven change has manifested itself in at least four discrete areas: 1) growth in the liquidity of the overall sports betting market, 2) an increase in marketplace competition resulting in decreased margins among bookmakers, 3 ) the emergence of in-game live betting and exponential growth in the volume of betting, and 4) a wider variety of so-called proposition or novelty bets that are not directly tied to the underlying game's outcome. ${ }^{147}$ All of these technology-driven factors, especially when coupled with important integrity and corruption considerations, are germane when discussing PASPA's utility moving forward.

${ }^{139}$ Richard Borghesi. Widespread Corruption in Sports Gambling: Fact or Fiction?, 74 S. Econ. J. 1063 (2008).

${ }^{140}$ Dan Bernhardt \& Steven Heston, Point Shaving in College Basketball: A Cautionary Tale for Forensic Economics, 48 Econ. Inquiry 14 (2010).

${ }^{141}$ See, e.g., Ian Preston \& Stefan Szymanski, Cheating in Contests, 19 Oxford Rev. Econ. Pol'y 612 (2003); Wolfgang Maennig, On the Economics of Doping and Corruption in International Sports, 3 J. Sports Econ. 61 (2002). The FBI also maintains a stand-alone Sports Bribery Program for investigating corruption in sporting contests. See Sports Bribery Program, Organized Crime, FBI, http://www.fbi.gov/about-us/investigate/organizedcrime/sports_bribe (last visited April 17, 2012).

${ }^{142}$ For a detailed discussion of how technological changes have impacted sports gambling, see George Diemer \& Ryan M. Rodenberg, Economics of Online Sports Gambling, in The Oxford Handbook on the Economics of Gambling (Leighton Vaughan Williams and Donald S. Siegel, eds., forthcoming 2012).

${ }^{143}$ Costa Rica, Curacao, and Antigua are popular choices among the thousands of internet-based sports books currently operating globally.

${ }^{144}$ One such example is Priomha Capital in Australia that has launched the CLONEY Multi-sport Fund, available at http://www.priomha.com (last visited April 17, 2012).

${ }^{145}$ See Diemer \& Rodenberg, supra note 142.

146 Pedro Raventos \& Sandro Zolezzi, Sportsbooks and Politicians: Place your Bet!, 64 J. Bus. Research 299 (2011).

${ }^{147}$ David Forrest, Betting and the Integrity of Sport, in Sports Betting: Law and Policy 14 (P.M. Anderson, et al eds., 2012). 


\section{Policy Implications}

\section{Government Regulation and Revenue Generation}

Politically, efforts to regulate sport betting and online gambling in general have been very contentious and frequently entangled due to the interaction between political actors and lobbyists serving the gambling industry's interests. An illustrative example was H.R. 3125, referred to as the Internet Gambling Prohibition Act of 2000. ${ }^{148}$ This was a bill to ban internet gambling and was defeated in great part due to the lobbying efforts of soon-to-be-convicted felon Jack Abramoff. ${ }^{149}$ Closely, since the turn of the millennium, there were several bills introduced in Congress to either regulate or ban gambling in sports. More often than not, these bills would not reach the vote stage and expire per sunset provisions at the conclusion of each session of Congress. Dating back to the $106^{\text {th }}$ Congress (1999-2000), these bills are summarized in Table $1 .{ }^{150}$

\section{Sport League Policy}

In a fascinating twist to the traditional stance American governing bodies have assumed against sports betting, NBA commissioner David Stern previoiusly alluded to a future where professional leagues will have more interaction with gambling operators, and remarked that nationally regulated betting on NBA games would be "a possibility [and] maybe a huge opportunity" for the league. ${ }^{151}$ Perhaps there is no better expression of at least a slight shift toward sport leagues' cooperation with the gaming industry than the NFL changing its policy on gambling advertisements. On April 12, 2012, the NFL's business ventures committee unanimously decided to amend a long-standing ban against in-stadium gambling advertisements, and thus allowed NFL teams to form commercial relationships with casinos, pursuant to certain restrictions regarding content and placement. ${ }^{152}$ In the college sports context, the

\footnotetext{
148 Bill Summary \& Status, 106th Congress, Libr. Cong., http://thomas.loc.gov/cgi-bin/bdquery/ z?d106:h.r.03125: (last visited April 17, 2012).

149 See generally Susan Schmidt \& James V. Grimaldi, How a Lobbyist Stacked the Deck, Wash. Post (October 16, 2005), available at http://www.washingtonpost.com/wp-dyn/content/ article/2005/10/15/AR2005101501539.html; David Postman \& Hal Bernton, Abramoff Used Area Foundation as Conduit for Money, Seattle Times (January 9, 2006), available at http:// seattletimes.nwsource.com/html/localnews/2002728644_lapin09m.html; Jack Abramoff, Capitol Punishment: The Hard Truth About Washington Corruption From America's Most Notorious Lobbyist (WND Books, 2011).

${ }^{150}$ For an in-depth analysis of legislative progress and the shift toward more regulation by certain state and federal political actors, see Anastasios Kaburakis \& Ryan M. Rodenberg, Gambling Sausage: Federal Legislation in the New Millennium, 16 Gaming L. Rev. \& Econ. (forthcoming 2012).

${ }^{151}$ Ian Thomsen, Weekly Countdown: Stern Open to Legalized Betting, Rule Changes, Sports Illustrated (December 11, 2009), available at http://sportsillustrated.cnn.com/2009/writers/ ian_thomsen/12/11/weekly.countdown/index.html.

${ }^{152}$ Daniel Kaplan, NFL Removes Ban On Casino Advertising For '12, '13 Seasons, Sports Bus. Daily (April 12, 2012), available at http://www.sportsbusinessdaily.com/Daily/ClosingBell/2012/04/12/NFL-casino.aspx. Restrictions also prohibit sponsoring casinos from operating a sports book.
} 


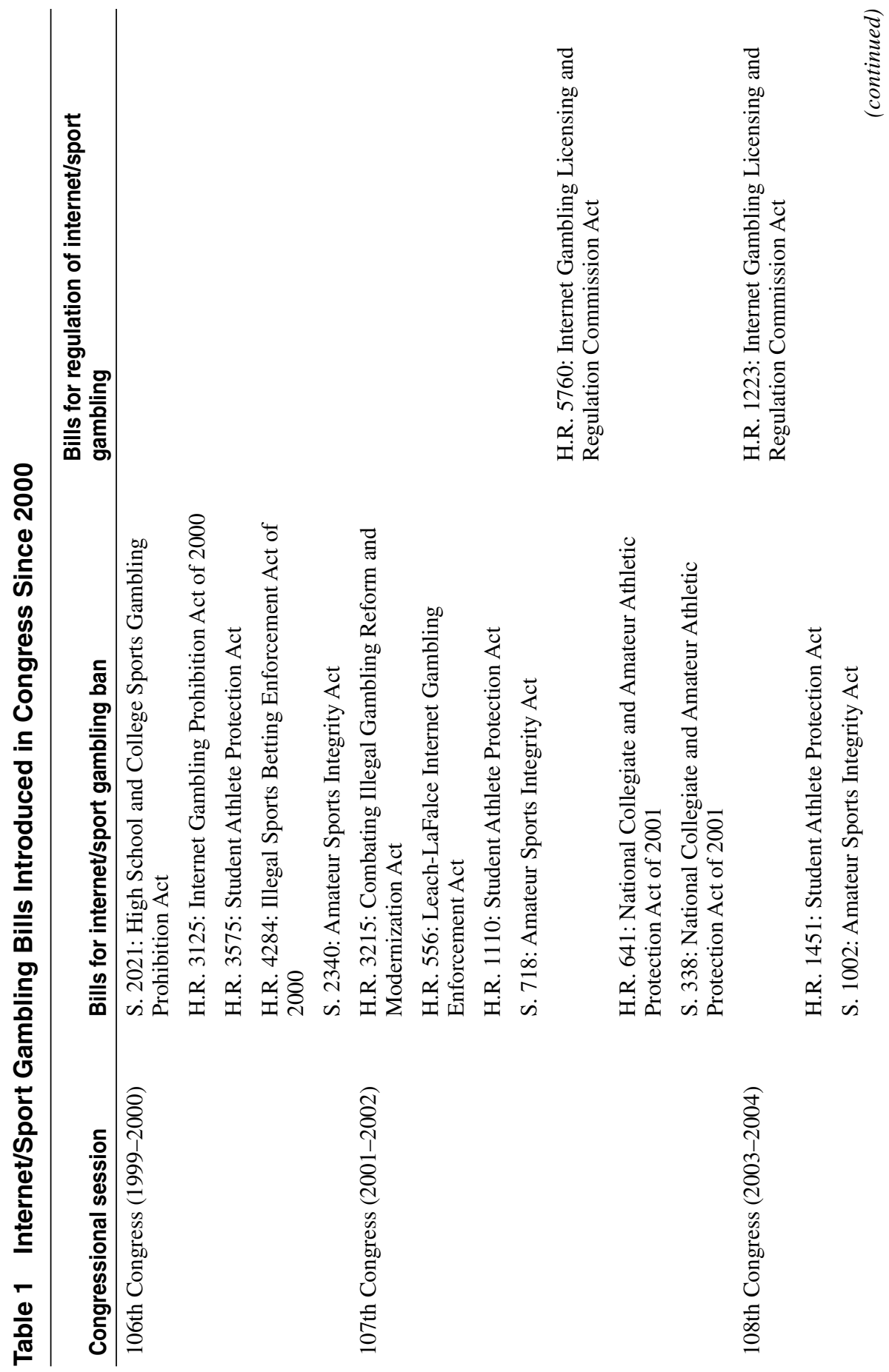




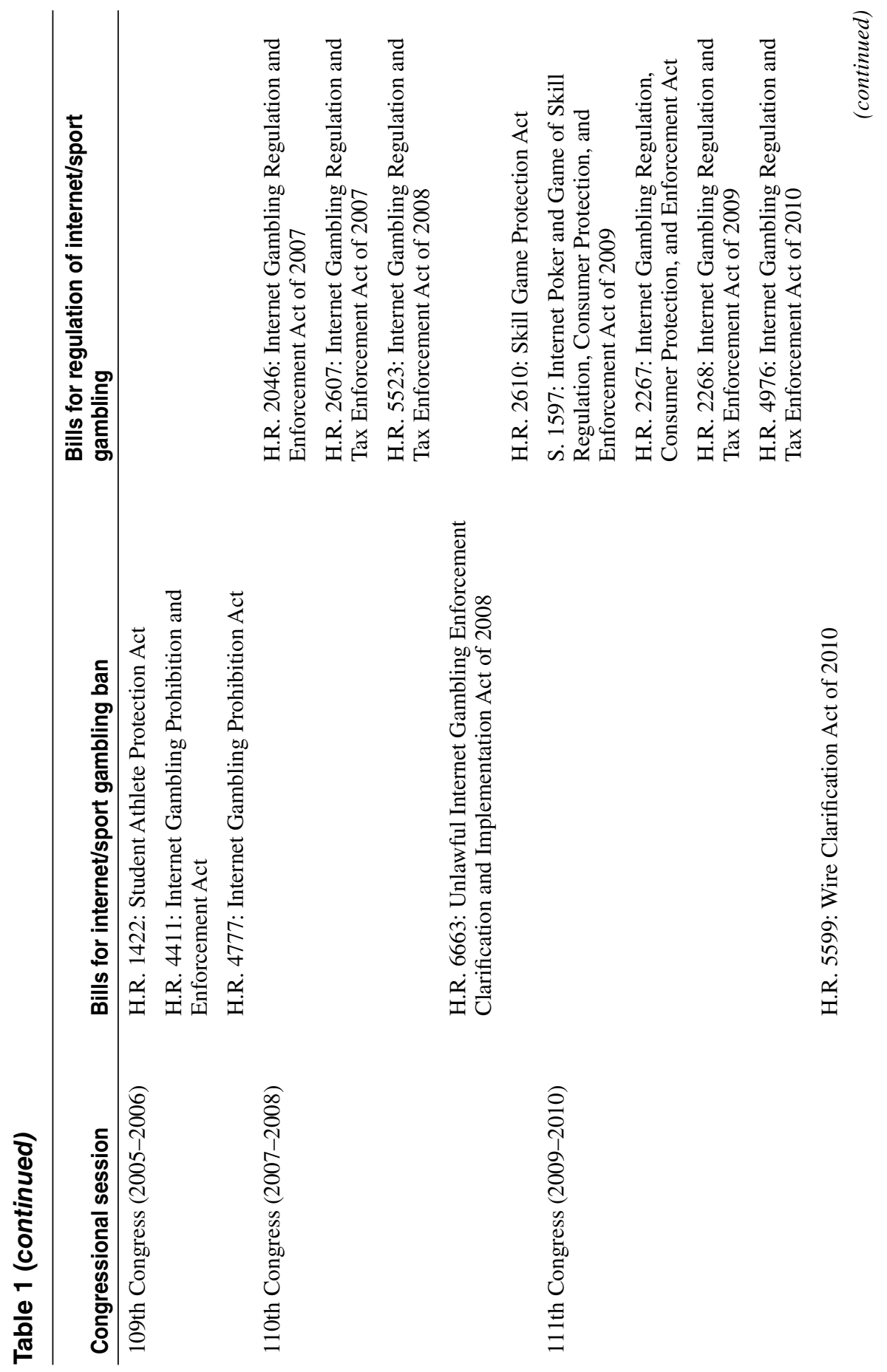




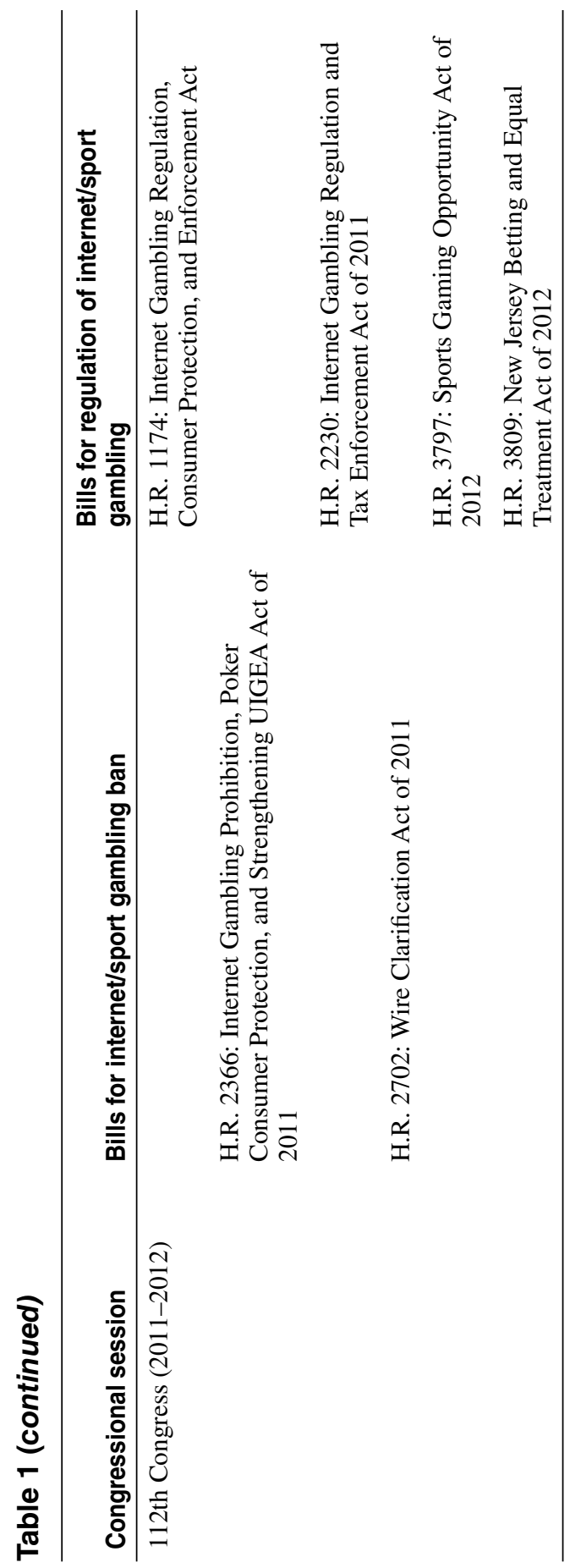


PAC-12 conference recently announced, in a multi-year agreement, that its conference championship basketball tournament would be moving to the MGM Grand Garden Arena, which is affiliated with the MGM Grand Casino in Las Vegas, Nevada. ${ }^{153}$ In addition, it is standard practice for U.S. leagues and professional sports organizations to partner with state lotteries, which frequently feature the most popular sports franchises on major revenue-producing scratch cards and related lottery products. ${ }^{154}$

\section{Conclusion}

A host of federal-level statutes have shaped sports betting for more than 50 years. For example, PASPA has served to limit state-sponsored sports gambling during the past two decades. Nonetheless, there appears to be a certain trend by which sports organizations are slowly entertaining more commercial partnerships with gaming operators, without at this time yielding completely to unfettered promotions of gambling products, and in particular sports betting services. Closely, the developments in New Jersey's pursuit of PASPA's repeal will determine a good deal in regard to sports gambling prospects in the future. With states' budgets in near-constant search of additional revenue generation, and with continuous pressure from constituents, including interests well rooted in the gambling industry, it appears foreseeable that the recent wave of legislation toward internet gambling and possibly sport betting at the federal level may assume a conclusive law-making trajectory. ${ }^{155}$ One analogy at the state level is the progress from strict anti-scalping laws to ticket reselling regulation and the creation of tickets' secondary market, from which considerable revenue in sales and income taxes is generated. ${ }^{156}$ There

${ }^{153}$ Men's Tournament to MGM Grand Garden, Pac-12 Conference (March 13, 2012), http://www. pac-12.org/SPORTS/BasketballM/Tabid/1449/Article/148514/Mens-Tournament-To-MGMGrand-Garden.aspx.

${ }^{154}$ See Stephen M. McKelvey, US Professional Sport Organization Policies Shift to Embrace Legalized Gambling Entities: A Roll of the Dice?, 14 J. Legal Aspects of Sport 23 (2004).

${ }^{155}$ For a detailed discussion of legalized gambling vis-à-vis state budgets, see Douglas M. Walker \& John D. Jackson, The Effect of Legalized Gambling on State Government Revenue, 29 Contemp. Econ. Pol'y 101 (2011).

${ }^{156}$ See, e.g., Bill King, Playing Politix: Ticketing companies guide the debate as politicians examine rules for selling, buying tickets, Sports Bus. J. (June 4-10, 2012) at 15-20 (outlining TicketMaster's and StubHub's opposing sides of the discourse, summarizing legislative progress in five states with pending bills on ticket market regulation, and citing a May 2012 Turnkey Sports Poll of 1,100 senior-level sports industry executives from professional and college sports, which found that $64 \%$ felt there should not be federal legislation regulating the secondary ticketing market in sports and live entertainment, as opposed to $29 \%$ who believe there should be federal legislation); see also Myles Kaufman, The Curious Case of US Ticket Resale Laws, SeatGeek.com (April 30, 2012), available at http://seatgeek.com/blog/ticket-industry/ticket-resale-laws (summarizing states' ticket resale laws); Chad Burgess, The Expert Series: Guide to the Secondary Ticket Market, SeatGeek.com (May 20, 2010), available at http://seatgeek.com/blog/ticket-industry/ secondary-ticket-market-and-resellers (providing several examples of the new industry revolving around the resale of tickets to sport and entertainment events). 
has been a considerable volume of both federal and state legislative bills introduced for regulation of internet gambling and sport betting, particularly subsequent to the New Jersey referendum in November 2011 and the state's sport betting legislation signed into law by the governor. As of June 2012, New Jersey is on track to be the first new state to operationalize sport betting, despite such move being in direct conflict with PASPA. ${ }^{157}$ Combined with legislative action on online and mobile gaming applications, ${ }^{158} \mathrm{New}$ Jersey is both on a collision course with the federal government, absent a repeal of PASPA, as well as being the state that others appear ready and eager to follow. ${ }^{159}$ In May and June 2012, California and New York state politicians introduced individual state bills to partially emulate New Jersey and introduce sport betting within their state borders if PASPA is no longer a barrier. ${ }^{160}$ This legislative commotion demonstrates a profound turn for potential gambling industry entrepreneurs and established global online gaming operators, who may return to the American market as swiftly as they departed upon the passage of UIGEA and numerous DOJ-led prosecutions.

\footnotetext{
${ }^{157}$ Kenny Walter, Beck: State ready to take on feds over sports betting, The Hub (June 7, 2012), available at http://hub.gmnews.com/news/2012-06-07/Front_Page/Beck_State_ready_to_take_ on_feds_over_sports_betti.html (describing state legislators support of Governor Christie's stance on sport betting and intentions to proceed with the new state law despite PASPA's federal ban, a proposed course of action that will almost certainly be challenged in court by the Department of Justice and/or one or more sports leagues deputized under PASPA to enforce the statute).
}

${ }^{158}$ A-Z Online Casinos, New Jersey Online Gambling: Good News and Bad (Update), AZOnlineCasinos.com (June 1, 2012) available at http://www.azonlinecasinos.com/news/20120601/ online-and-mobile-gambling-good-news-and-bad/ (describing legislative progress in the New Jersey Senate on mobile and online gambling legislation).

159 Chad Millman, NY, NJ Want Sports Betting Legalized, ESPN Insider (May 25, 2012), available at http://insider.espn.go.com/insider/blog/_name/millman_chad/id/7971201/charles-hynescomes-favor-legalization-sports-betting (outlining Brooklyn District Attorney Charles Hynes' support of recent legislative attempts to regulate sport betting).

${ }^{160}$ Carl Campanile, They're off! Pols push sports bets, N.Y. Post (May 21, 2012), available at http://www.nypost.com/p/news/local/they_re_off_pols_push_sports_bets_vgQIPyFOPIXUhhUK3NUaBI (reporting that Democrat State Senator Tony Avella was preparing a sports betting bill, which had the support of Brooklyn District Attorney Charles Hynes, and that Avella cited research that points to a potential revenue generation upward of $\$ 2$ billion for the state, in lieu of data projecting illegal sports betting in New York City alone between \$15-30 billion per year); Patrick McGreevy, California Lawmakers Vote for Legalizing Sports Betting, L.A. Times (May 29, 2012), available at http://latimesblogs.latimes.com/california-politics/2012/05/sports-incalifornia.html (summarizing the adoption by the California Senate of a bill (SB 1390, passed by a vote of 32-2) introduced by state Senator Roderick Wright). 